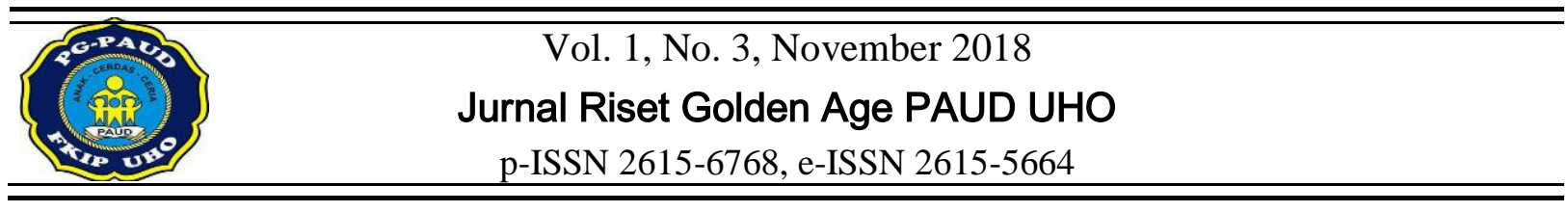

\title{
MENINGKATKAN KEMAMPUAN MEMBACA PERMULAAN ANAK MELALUI MEDIA
} KARTU HURUF

\author{
Nur Eka Putri ${ }^{1)}$, Ahid Hidayat ${ }^{1)}$ \\ ${ }^{1}$ Jurusan PG-PAUD, Universitas Halu Oleo. Jln. H.E.A Mokodompit, Kendari 93232, Indonesia.
}

\begin{abstract}
Abstrak
Penelitian ini bertujuan untuk meningkatkan kemampuan membaca permulaan melalui media kartu huruf di Kelompok B TK Kartika XX-46 Kendari. Penelitian ini adalah penelitian tindakan kelas (PTK). Penelitian ini dilaksanakan dalam dua siklus dimana setiap siklus terdiri dari empat kali pertemuan. Tahap-tahap dalam penelitian ini mengikuti prosedur penelitian tindakan kelas, yaitu: (1) perencanaan, (2) pelaksanaan, (3) observasi atau pengamatan, dan (4) refleksi. Subjek dalam penelitian ini adalah guru dan anak didik di Kelompok B TK Kartika XX-46 Kendari yang berjumlah 20 anak didik yang terdiri atas 9 orang anak perempuan dan 11 orang anak laki-laki dengan rentang usia 5-6 tahun. Hasil penelitian ini menunjukkan adanya peningkatan hasil belajar. Sebelum tindakan diperoleh persentase sebesar $40 \%$ dan mengalami peningkatan pada siklus I yaitu sebesar $15 \%$ sehingga menjadi $65 \%$. Pada siklus II mengalami peningkatan sebesar $20 \%$ dari siklus I sehingga menjadi $85 \%$. Dengan demikian dapat disimpulkan bahwa kemampuan membaca permulaan anak di Kelompok B TK Kartika XX-46 Kendari dapat ditingkatkan melalui media kartu huruf.
\end{abstract}

Kata Kunci: Kemampuan Membaca, Permulaan Anak, Media Kartu Huruf

\section{IMPROVE CHILDREN'S STARTING READING THROUGH LETTER CARD MEDIA}

\begin{abstract}
This research aims to improve the ability to read the beginning through the media letter card in the group B TK Kartika XX-46 Kendari. This research is a class action research (PTK). The study was conducted in two cycles where each cycle consisted of four meetings. The stages in this study followed the procedures of class action research, namely: (1) planning, (2) implementation, (3) observation or observation, and (4) reflection. The subject in this study is the teacher and the student of the group $B$ TK Kartika XX-46, a total of 20 students consisting of 9 daughters and 11 boys with a range of 5-6 years old. The results of this study showed increased learning outcomes. Before the action gained a percentage of $40 \%$ and increased in cycle I of $15 \%$ to $65 \%$. In cycle II experienced an increase of $20 \%$ from the I cycle to $85 \%$. Thus it can be concluded that the ability to read the child's start in the group B TK Kartika XX-46 can be upgraded through the Media letter card.
\end{abstract}

Keywords: Ability To Read, Start Children, Media Card Letters

\section{PENDAHULUAN}

Undang-Undang Nomor 20 Tahun 2003 tentang Sistem Pendidikan Nasional pasal 1 ayat 14 disebutkan bahwa pendidikan anak usia dini adalah suatu upaya pembinaan yang ditujukan kepada anak sejak lahir sampai usia enam tahun, yang dilakukan melalui pemberian rangsangan pendidikan untuk membantu pertumbuhan dan perkembangan jasmani dan rohani, agar anak memiliki kesiapan dalam memasuki pendidikan lebih lanjut (Depdiknas, 2003 : 15).

Pendidikan anak usia dini menitikberatkan pada aspek perkembangan fisik motorik, kognitif, bahasa, sosial emosional, serta nilai agama dan moral. Semua aspek tersebut harus distimulasi secara menyeluruh agar anak memiliki berbagai potensi yang harus dioptimalkan.

Masa usia dini merupakan masa yang tepat untuk meningkatkan segala potensi dan kecerdasan anak. Masa ini merupakan saat yang tepat untuk meletakkan dasar pertama dalam meningkatkan kemampuan fisik, kognitif, bahasa, seni, sosial emosional, disiplin diri, nilai-nilai agama, konsep diri dan kemandirian. Pengembangan potensi yang terarah akan berdampak pada kehidupan anak selanjutnya.

Undang-undang No 20 Tahun 2003 tentang Sistem Pendidikan Nasional setiap 
warga negara Republik Indonesia memperoleh sekurang-kurangnya pengetahuan membaca, menulis dan berhitung serta mempergunakan bahasa Indonesia.

Salah satu kemampuan anak yang harus dikembangkan adalah kemampuan membaca. Perkembangan membaca merupakan salah satu dari kemampuan dasar yang harus dimiliki anak. Membaca merupakan potensi yang sangat penting untuk dikembangkan pada anak usia dini. Melalui membaca anak dapat memperluas wawasan dan menambah pengetahuan sebagai bekal kehidupan anak selanjutnya. Kegiatan membaca merupakan kegiatan yang menjadi jantung bagi pendidikan. Hal ini berarti bahwa tidak ada kegiatan pembelajaran tanpa membaca.

Membaca bagi anak usia dini tentunya sesuatu yang sangat rumit bagi anak untuk itu sebelum anak membaca lancar anak harus mengenal huruf terlebih dahulu. Anak-anak terlebih dahulu harus mengetahui bunyi dari setiap huruf dan mampu membedakan setiap huruf-huruf alfabet agar dapat dengan mudah untuk menyusun dan membaca pada sebuah kata.

Kemampuan membaca sangat penting bagi anak. Dhieni dkk. (2006: 5.4) mengatakan bahwa anak-anak yang gemar membaca akan mempunyai rasa kebahasaan yang lebih tinggi. Mereka akan berbicara, menulis dan memahami gagasan-gagasan rumit secara lebih baik.

Kemampuan kesiapan membaca anak perlu diketahui oleh guru dan orang tua, untuk memberikan stimulasi tepat sehingga kemampuan membaca anak dapat berkembang dengan baik. Menurut Dhieni (2006: 5.13) kemampuan kesiapan membaca yang akan dikembangkan yaitu: kemampuan membedakan auditorial, kemampuan diskriminasi visual, kemampuan perseptual motoris, kemampuan bahasa lisan, membangun sebuah latar belakang pengalaman, interpretasi gambar, progresi dari kiri ke kanan, penggunaan bahasa mulut, pengenalan melihat kata, literasi, koordinasi gerak.

Kemampuan belajar membaca membutuhkan waktu, kesabaran dan kesiapan. Eliason (1994) dalam Susanto (2014: 86) anak yang menyukai gambar atau huruf sejak awal perkembangannya akan mempunyai keinginan membaca lebih besar karena mereka tahu bahwa membaca, membuka pintu baru, membenahi informasi, dan menyenangkan.
Kemampuan membaca pada anak berkembang dalam beberapa tahap. Steinberg (1982: 28) dalam Susanto (2014: 90) membagi tahap perkembangan dalam empat bagian yaitu tahap timbulnya kesadaran terhadap tulisan, tahap membaca gambar, tahap pengenalan bacaan, tahap membaca lancar

Kemampuan membaca permulaan merupakan salah satu bagian dari bahasa. Menurut Sareb dalam Dewi (2012: 12) mengungkapkan bahwa membaca permulaan menekankan pengkondisian anak didik untuk masuk dan mengenal bahan bacaan, namun belum sampai pada tahap pemahaman yang mendalam akan meteri bacaan.

Masa prasekolah anak diberikan stimulus untuk dapat membaca permulaan. Menurut Susanto (2014: 83) membaca permulaan adalah membaca yang diajarkan secara terprogram kepada anak prasekolah, dengan memberikan perkataan-perkataan utuh dan bermakna melalui permainan dan kegiatan yang menarik bagi anak.

Dewi (2012: 13) kemampuan membaca permulaan adalah membaca yang dilaksanakan di TK yang dilakukan secara terprogram kepada anak prasekolah, dimulai dengan mengenalkan huruf-huruf dan lambang-lambang tulisan. Dhieni dkk. (2006: 5.5) kemampuan membaca permulaan merupakan suatu kesatuan kemampuan yang terpadu yang mencakup beberapa kemampuan seperti mengenali huruf dan kata-kata, menghubungkannya dengan bunyi, maknanya serta menarik kesimpulan mengenai maksud bacaan. Kemampuan membaca termasuk kegiatan yang kompleks dan melibatkan berbagai keterampilan.

Berdasarkan pendapat diatas dapat disimpulkan bahwa kemampuan membaca permulaan adalah kemampuan yang diberikan kepada anak usia dini sebelum memasuki jenjang pendidikan dasar yang dilakukan secara terprogram yang diawali dengan mengenalkan simbol-simbol huruf abjad yang dapat terlihat saat anak mampu menyebutkan suatu simbol huruf, kemampuan anak dalam memahami huruf dan menghubungkannya dengan bunyi dari huruf atau rangkaian kata sehingga diperoleh informasi.

Berdasarkan hasil observasi pada Kelompok B di TK Kartika bahwa kemampuan membaca anak dalam kegiatan pembelajaran masih sangat kurang. Hanya 40\% atau 8 anak dari 20 anak yang sudah mampu membaca dan mulai belajar membaca apabila ditunjukkan satu 
kata dengan rincian 2 orang anak memperoleh bintang $(* * * *)$ atau Berkembang Sangat Baik (BSB) dan 6 orang anak memperoleh bintang (***) atau Berkembang Sesuai Harapan (BSH). Hal tersebut diakibatkan guru belum mampu meningkatkan ide-ide atau media yang dapat meningkatkan aspek-aspek perkembangan membaca anak dalam kegiatan pembelajaran. Terutama pada aspek membaca huruf, dimana cara guru mengenalkan huruf pada anak langsung menyebutkan bunyi huruf sambil menunjuk huruf kemudian cenderung memberikan kegiatan berupa penugasan bentuk lembaran kerja.

Stimulus yang diberikan pada anak untuk meningkatkan kemampuan membaca permulaan dapat dilakukan dengan menggunakan berbagai cara, salah satunya yaitu menggunakan media yang menarik bagi anak. Media dapat membantu guru dalam menyampaikan pembelajaran kepada anak agar anak tidak jenuh dalam proses pembelajaran.

Media yang dapat membantu meningkatkan kemampuan membaca anak salah satunya yaitu media kartu huruf. Media kartu huruf menjadi salah satu alternatif bagi seorang guru untuk memberikan pelajaran membaca kepada anak dengan cara bermain, yang sudah menjadi dunia anak serta prinsip dari pembelajaran anak usia dini yaitu bermain sambil belajar.

Media kartu huruf tergolong dalam jenis media visual. Suharso dan Ana Retnoningsih dalam Waraningsih (2014: 25) kartu adalah kertas tebal yang berbentuk persegi panjang. Arsyad (2011: 119) mengemukakan bahwa kartu huruf adalah kartu kartu abjad yang berisi gambar, huruf, tanda simbol, yang meningkatkan atau menuntun anak yang berhubungan dengan simbol-simbol tesebut. Gambar yang terdapat pada kartu biasanya berupa simbol-simbol huruf.

Maimunah Hasan dalam Trisniwati (2014: 15) mengungkapkan bahwa kartu huruf adalah penggunaan sejumlah kartu sebagai alat bantu untuk belajar membaca dengan cara melihat dan mengingat bentuk huruf dan gambar pada kartu. Anak dapat belajar mengingat huruf dengan melihat simbol huruf dan gambar pada kartu huruf.

Media kartu huruf terdiri dari huruf-huruf yang dituliskan pada potongan-potongan karton. Potongan-potongan kartu huruf tersebut dapat dipindahkan sesuai keinginan pembuat suku kata, kata, maupun kalimat. Penggunaan kartu huruf sangat menarik perhatian anak dan sangat mudah digunakan dalam pembelajaran membaca, karena kartu huruf dapat melatih kreatifitas anak dalam menyusun huruf sesuai keinginannya.

Media kartu huruf memiliki berbagai manfaat dalam membantu guru menyampaikan pembelajaran. Manfaat kartu huruf dalam pembelajaran membaca untuk anak usia dini yaitu: meningkatnya kemampuan anak dalam menghafal dan menguasai huruf abjad dalam waktu cepat, membantu guru dalam mengajar, memperbanyak perbendaharaan kata anak, mengembangkan daya ingat otak kanan anak, melatih kemampuan kosentrasi anak (Ningsih, 2014: 21)

Berdasarkan pendapat tersebut dapat disimpulkan bahwa kartu huruf merupakan salah satu media visual yang berisi gambar dan simbol huruf, dengan tujuan sebagai alat bantu untuk belajar membaca dengan mengingat simbol huruf. Namun, pada penelitian ini peneliti menggunakan kartu huruf yang dibuat sendiri dengan berbagai bentuk segi empat yang berisi simbol huruf. Bentuk kartu huruf disesuaikan dengan tema pembelajaran yang sedang berlangsung ketika penelitian.

\section{METODE}

Jenis yang digunakan dalam penelitian ini adalah Penelitian Tindakan Kelas (PTK). Arikunto (2010: 135) menyatakan bahwa penelitian tindakan kelas (classroom action research) adalah penelitian yang dilakukan oleh guru ke kelas atau di sekolah tempat ia mengajar dengan penekanan pada penyempurnaan atau peningkatan proses dan praksis pembelajaran. Penelitian tindakan kelas bertujuan untuk memperbaiki dan meningkatkan kualitas pembelajaran, utamanya meningkatkan kemampuan membaca permulaan anak melalui media kartu huruf pada anak kelompok B di TK Kartika XX-46 Kendari.

Penelitian ini dilaksanakan di TK Kartika XX-46 Kendari yang berada di Jalan Lawata No. 01 Kecamatan Mandonga Kota Kendari yang dilaksanakan pada 13 Februari 2016 sampai 19 Maret 2016 semester genap tahun ajaran 2015/2016.

Subyek penelitian tindakan kelas ini adalah guru dan 20 anak dengan 9 anak perempuan dan 11 anak laki-laki kelompok B TK Kartika XX-46. Objek yang akan diteliti adalah peningkatan kemampuan membaca permulaan anak melalui media kartu huruf. 
Faktor yang diteliti dalam penelitian ini yaitu: (a) Melihat aktivitas anak selama mengikuti proses pembelajaran untuk meningkatkan kemampuan membaca permulaan dalam kegiatan mengenali huruf abjad yang terlihat saat anak mampu menyebutkan huruf, menyebutkan huruf vokal, menyebutkan kata dengan huruf awal yang sama dan menyusun huruf sesuai dengan urutan menjadi sebuah kata dengan menggunakan media kartu huruf; (b) Melihat aktivitas guru dalam melaksanakan proses pembelajaran tentang kemampuan membaca permulaan anak, dalam hal ini kegiatan mengenalkan huruf pada anak melalui media kartu huruf.

Prosedur pelaksanaan penelitian tindakan kelas ini dilaksanakan dalam dua siklus, kedua tahapan tersebut terdiri dari perencanaan tindakan, pelaksanaan tindakan, pengamatan tindakan dan refleksi tindakan.

Teknik pengumpulan data yang dilakukan pada penelitian ini dengan menggunakan cara:

a. Observasi adalah sistem atau rencana untuk mengamati perilaku. Selain itu observasi juga diartikan sebagai pengamatan dan pencatatan secara sistematik terhadap gejalah yang tampak pada objek penelitian.

b. Wawancara dapat dilakukan dengan cara melakukan percakapan atau tanya jawab dengan orang lain atau responden yang berhubungan dengan penelitian. Hal ini dibutuhkan untuk memperkuat data yang didapat melalui observasi

c. Dokumentasi merupakan suatu teknik pengumpulan data dengan menghimpun dan menganalisis dokumen-dokumen. Dokumendokumen yang dimaksud adalah dokumen pribadi siswa, foto-foto aktivitas guru dan anak, referensi-referensi seperti rapor siswa dan absensi siswa. Data ini dapat bermanfaat bagi peneliti untuk menguji, menafsirkan bahkan untuk meramalkan jawaban dari permasalahan penelitian.

Teknik analisis data yang digunakan dalam penelitian ini disesuaikan dengan teknik penilaian di Taman Kanak-kanak yaitu dengan menggunakan tanda sebagai berikut: $*=$ Belum Berkembang $(\mathrm{BB}), * *=$ Mulai Berkembang $(\mathrm{MB}), * * *=$ Berkembang Sesuai Harapan $(\mathrm{BSH}), * * * *=$ Berkembang Sangat Baik (BSB) (Depdiknas, 2004: 26).

Indikator kinerja dalam penelitian ini ditentukan oleh Taman Kanak-kanak TK Kartika XX-46 Kendari yang terdiri dari indikator proses dan indikator hasil (nilai) anak didik. Dari segi indikator proses pembelajaran, tindakan dikatakan berhasil apabila minimal $85 \%$ proses pelaksanaan tindakan sesuai dengan skenario pembelajaran, baik yang dilakukan oleh guru maupun anak didik. Dari segi indikator hasil, tindakan dikatakan berhasil apabila anak didik telah mencapai nilai berkembang sesuai harapan (BSH) dan berkembang sangat baik (BSB) minimal $75 \%$ baik secara individual maupun klasikal.

\section{HASIL DAN PEMBAHASAN}

Sebelum penelitian ini dilaksanakan, peneliti terlebih dahulu melakukan pertemuan awal dengan kepala TK Kartika XX-46 Kendari yaitu pada tanggal 29 Oktober 2015, pertemuan ini bermaksud untuk menyampaikan tujuan dari peneliti yaitu mengadakan penelitian di TK Kartika XX-46 Kendari. Selanjutnya, kepala TK Kartika XX-46 Kendari mengarahkan peneliti untuk berdiskusi dengan guru Kelompok B. Setelah itu, peneliti melakukan observasi awal di TK Kartika XX-46 Kendari setelah menemui guru Kelompok B dan meminta untuk menjadi observer peneliti.

Berdasarkan hasil observasi dan wawancara yang dilakukan peneliti menunjukkan bahwa kemampuan membaca permulaan anak pada anak Kelompok B masih sangat rendah yaitu berada pada taraf Mulai Berkembang (MB) atau dengan simbol bintang (**) serta media pembelajaran yang digunakan dalam proses pembelajaran membaca anak masih kurang bervariasi.

Berdasarkan permasalahan yang dihadapi tersebut, maka peneliti berusaha merancang suatu media yang menarik dan menyenangkan bagi anak untuk meningkatkan kemampuan membaca permulaan anak melalui media kartu huruf. Setelah itu, peneliti bersama guru Kelompok B TK Kartika XX-46 Kendari sepakat untuk bekerjasama dan menjadi mitra dalam kegiatan penelitian. Selanjutnya, peneliti menyusun Rencana Kegiatan Mingguan (RKM) yang kemudian dijabarkan menjadi Rencana Kegiatan Harian (RKH). Penelitian ini sesuai dengan jadwal yang telah disusun sebelumnya, yaitu dilaksanakan dengan dua siklus kegiatan pembelajaran, dimana setiap siklus terdiri dari empat kali pertemuan dengan indikator meningkatkan kemampuan membaca permulaan anak melalui media kartu huruf. 
Adapun hasil observasi awal sebelum pelaksanaan tindakan penelitian, yaitu meningkatkan kemampuan membaca permulaan anak pada Kelompok B TK Kartika XX-46 Kendari dapat dilihat pada tabel perhitungan nilai individual pada observarsi awal Berdasarkan data yang ditampilkan pada tabel tersebut menunjukkan bahwa anak didik mencapai $1,50-2,49$ atau berada pada taraf kategori nilai bintang $(* *)$ atau Mulai Berkembang. Berdasarkan hasil pengolahan data tersebut, selanjutnya dilakukan analisis keberhasilan secara klasikal untuk penilaian awal kegiatan pembelajaran sebelum dilaksanakan kegiatan meningkatkan kemampuan membaca permulaan anak melalui media kartu huruf pada anak Kelompok B TK Kartika XX-46 Kendari dan diperoleh hasil seperti yang ditampilkan pada tabel 1. yaitu sebagai berikut.

Tabel 1. Perhitungan Nilai Klasikal pada Observasi Awal

\begin{tabular}{lcc}
\hline \multicolumn{1}{c}{ Kategori } & Jumlah & (\%) \\
\hline $\begin{array}{l}\text { Berkembang } \\
\text { Sangat Baik }\end{array}$ & 2 & $10 \%$ \\
\hline $\begin{array}{l}\text { Berkembang } \\
\text { Sesuai Harapan }\end{array}$ & 6 & $30 \%$ \\
\hline $\begin{array}{l}\text { Mulai } \\
\text { Berkembang }\end{array}$ & 9 & $45 \%$ \\
\hline $\begin{array}{l}\text { Belum } \\
\text { Berkembang }\end{array}$ & 3 & $15 \%$ \\
\hline \multicolumn{1}{c}{ Jumlah } & 20 & $100 \%$ \\
\hline
\end{tabular}

Data hasil perhitungan pada tabel tersebut, dapat dikatakan bahwa secara klasikal dalam meningkatkan kemampuan membaca permulaan anak melalui media kartu huruf pada Kelompok B TK Kartika XX-46 Kendari saat terakhir penilaian, rata-rata anak memiliki perolehan nilai bintang (**) atau Mulai Berkembang yang diperoleh 9 orang anak atau sebesar $45 \%$, dengan kata lain sebagian besar anak didik belum mampu memenuhi target ketercapaian dalam indikator keberhasilan dalam kegiatan penilaian. Tampak dalam penilaian ada 6 orang anak yang memperoleh bintang (***) atau Berkembang Sesuai Harapan (BSH) dengan persentase sebesar 30\% dan 2 orang anak yang memperoleh bintang (****) atau Berkembang Sangat Baik dengan persentase sebesar $10 \%$ dan 3 orang anak memperoleh bintang $(*)$ atau Belum Berkembang (BB) dengan persentase sebesar
15\%. Berdasarkan hasil tersebut peneliti merumuskan kembali dengan guru Kelompok B untuk menerapkan kegiatan pembelajaran dalam rangka meningkatkan kemampuan membaca permulaan anak melalui media kartu huruf pada tindakan siklus I.

Tindakan pada siklus I terdiri atas empat kegiatan harian, peneliti melaksanakan pembelajaran sesuai dengan Rencana Kegiatan Harian (RKH) dengan tema alat transportasi, sub tema alat transportasi darat dengan tema spesifik mobil, motor, becak, dan delman yang dilaksanakan pada tanggal $7,8,10$, dan 11 Maret 2016. Tindakan penelitian ini dilaksanakan di ruang Kelompok B TK Kartika XX-46 Kendari, anak telah siap belajar dengan guru dengan acuan pembelajaran yaitu peningkatan kemampuan membaca permulaan anak melalui media kartu huruf. Adapun indikator yang akan dicapai pada tiap pertemuan yaitu mengenal simbol-simbol huruf, menyebutkan huruf vokal, menyebutkan kata yang dengan huruf awal yang sama dan menyusun huruf.

Hasil analisis observasi guru sesuai dengan lembar observasi sebanyak 14 aspek yang diamati dan harus dicapai oleh guru. Pada siklus I persentase aspek yang diamati mencapai $78,6 \%$ dengan rincian dari 14 aspek hanya 11 aspek yang dilaksanakan. Aspek yang diamati diantaranya yaitu: (a) guru menyampaikan tujuan pembelajaran; (b) guru melakukan apersepsi yang berhubungan dengan tema/subtema pembelajaran; (c) guru menyiapkan media pembelajaran (kartu huruf); (d) guru menjelaskan tujuan pembelajaran/kegiatan yang akan dilaksanakan yang berkaitan dengan media kartu huruf; (e) guru menentukan satu kata yang sesuai dengan tema; (f) guru mengenalkan huruf pada kata yang telah ditentukan; (g) guru mempersilahkan anak untuk menyebutkan huruf vokal; (h) guru mempersilahkan anak untuk menyebutkan kata yang memiliki huruf awal yang sama; (i) guru mengacak kartu huruf; (j) guru mempersilahkan anak secara bergantian menyusun huruf sehingga membentuk kata; (k) guru bimbingan anak dalam menggunakan media kartu huruf; (l) guru mengadakan tanya jawab tentang kegiatan yang telah dilakukan; (m) guru memberikan motivasi, penguatan dan penghargaan pada anak; dan (n) memberikan kesimpulan terhadap kegiatan yang dilakukan hari ini.

Aspek yang tidak tercapai sebanyak 3 aspek dengan persentase $21,4 \%$ yaitu guru 
mengadakan tanya jawab tentang kegiatan yang dilakukan hari ini dan guru memberikan kesimpulan terhadap kegiatan yang dilakukan hari ini. Untuk lebih jelasnya dapat digambarkan pada histogram berikut:

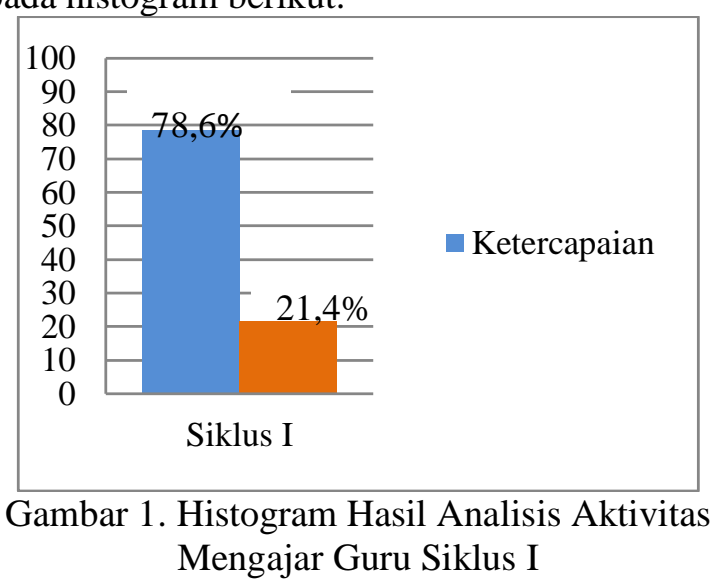

Berdasarkan histogram tersebut aktivitas mengajar guru pada siklus I dengan empat kali pertemuan menunjukkan bahwa dari 14 aspek yang diamati dalam proses pembelajaran aspek yang terlaksana hanya 11 aspek dengan persentase sebesar 78,6\% sedangkan yang tidak terlaksana 3 aspek dengan persentase $21,4 \%$, dengan demikian hasil aktivitas mengajar guru pada siklus I belum maksimal sedangkan standar ketercapaian aktivitas mengajar guru yang harus dicapai $\geq 75 \%$ sehingga dapat dikatakan berhasil.

Hasil analisis observasi anak sesuai dengan lembar observasi sebanyak 14 aspek yang diamati dan harus dicapai oleh anak. Pada siklus I persentase aspek yang diamati mencapai 64,3\% dengan rincian dari 14 aspek hanya 9 aspek yang dilaksanakan. Aspek yang diamati diantaranya yaitu: (a) mendengarkan guru menyampaikan tujuan pembelajaran; (b) aktif pada kegiatan apersepsi; (c) memperhatikan guru saat memperkenalkan media kartu huruf; (d) mendengarkan penjelasan guru mengenai tujuan pembelajaran/kegiatan yang akan dilaksanakan, berkaitan dengan media kartu huruf; (e) anak antusias bertanya; (f) anak memperhatikan kata; (g) anak menyebutkan huruf pada media kartu huruf; (h) anak menyebutkan huruf vokal pada kata; (i) anak menyebutkan kata yang memiliki huruf awal yang sama; (j) anak berdiri berbaris di ruang kelas; (k) anak menyususn huruf pada kartu huruf menjadi sebuah kata; (l) anak mendapatkan bimbingan dari guru dalam menggunakan media kartu huruf; (m) anak melakukan tanya jawab dengan guru tentang kegiatan yang dilakukan hari ini; (n) anak mendengarkan nasehat-nasehat dan kesimpulan terhadap kegiatan yang dilakukan hari ini.

Aspek yang tidak tercapai sebanyak 5 aspek dengan persentase $35,7 \%$ yaitu mendengarkan guru menyampaikan tujuan pembelajaran, melakukan tanya jawab dengan guru tentang media kartu huruf dan mendengarkan nasehat-nasehat dan kesimpulan terhadap kegiatan yang dilakukan hari ini. Untuk lebih jelasnya dapat digambarkan dengan histogram berikut:

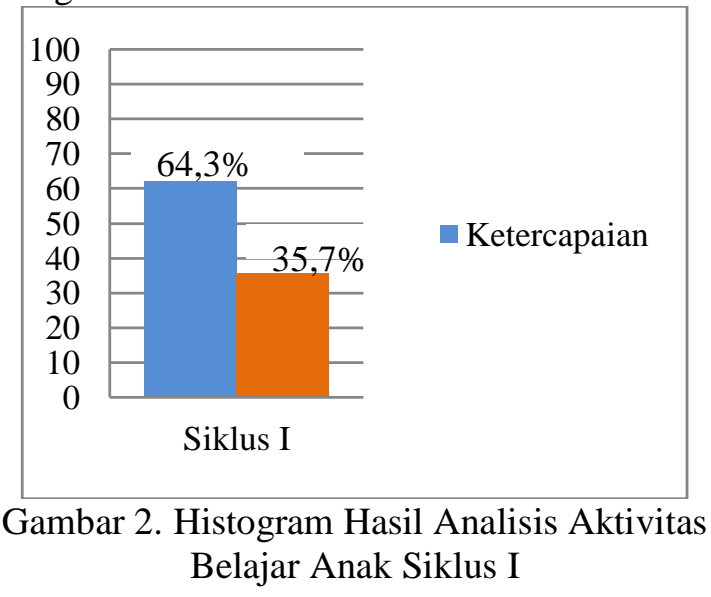

Berdasarkan histogram tersebut aktivitas belajar anak pada siklus I menunjukkan bahwa dari 14 aspek yang diamati dalam proses pembelajaran aspek yang terlaksana hanya 9 aspek dengan persentase sebesar 64,3\% sedangkan yang tidak terlaksana 5 aspek dengan persentase $35,7 \%$, dengan demikian hasil aktivitas belajar anak pada siklus I belum maksimal sedangkan standar ketercapaian aktivitas belajar anak yang harus dicapai $\geq 85 \%$ sehingga dapat dikatakan berhasil.

Analisis keberhasilan secara klasikal dan diperoleh dari data hasil nilai individual seperti tampak pada tabel 2. berikut ini.

Tabel 2. Perhitungan Nilai Klasikal pada Tindakan Siklus I

\begin{tabular}{ccc}
\hline Kategori & $\begin{array}{c}\text { Jumlah } \\
\text { Anak }\end{array}$ & $\begin{array}{c}\text { Persentase } \\
(\mathbf{\%})\end{array}$ \\
\hline $\begin{array}{c}\text { Berkembang } \\
\text { Sangat Baik }\end{array}$ & 6 & 30 \\
\hline $\begin{array}{c}\text { Berkembang } \\
\text { Sesuai Harapan }\end{array}$ & 7 & 35 \\
\hline $\begin{array}{c}\text { Mulai } \\
\text { Berkembang }\end{array}$ & 5 & 25 \\
\hline $\begin{array}{c}\text { Belum } \\
\text { Berkembang }\end{array}$ & 2 & 10 \\
\hline Jumlah & 20 & 100 \\
\hline
\end{tabular}


Berdasarkan data hasil yang diperoleh pada tabel tersebut terlihat bahwa secara klasikal kegiatan meningkatkan kemampuan membaca permulaan anak melalui media kartu huruf di Kelompok B TK Kartika XX-46 Kendari pada tahap evaluasi siklus I, rata-rata anak memperoleh nilai bintang (***) atau Berkembang Sesuai Harapan (BSH) dengan persentase $35 \%$ yaitu 7 orang anak, 6 orang anak dengan nilai bintang $(* * * *)$ atau Berkembang Sangat Baik (BSB) dengan persentase $30 \%$, dan 5 orang anak memperoleh nilai bintang $(* *)$ atau Mulai Berkembang (MB) dengan persentase $25 \%$, dan 2 orang anak memperoleh nilai bintang (*) atau Belum Berkembang (BB) dengan persentase $10 \%$ yang dapat digambarkan melalui histogram berikut ini:

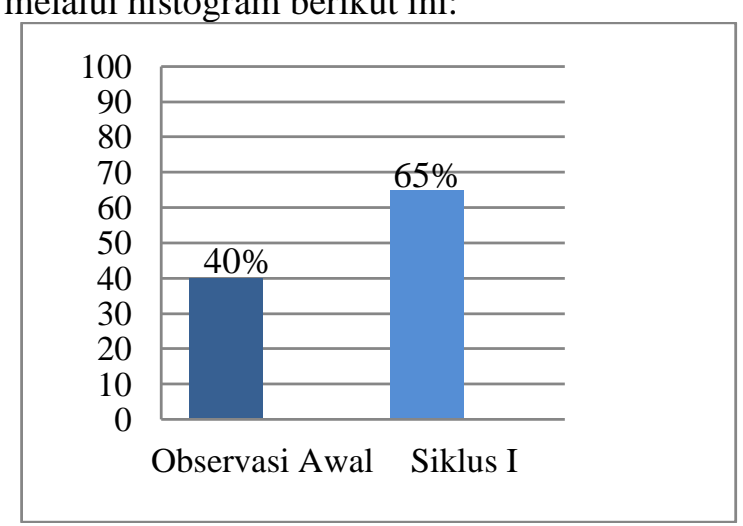

Gambar 3. Histogram Hasil Analisis Kemampuan Membaca Permulaan Anak Observasi Awal dan Siklus I

Berdasarkan hasil evaluasi tersebut, sebagian besar anak sudah dapat melaksanakan kegiatan dengan baik, namun belum mencapai indikator kinerja yaitu $\geq 75 \%$ jika anak memperoleh nilai Berkembang Sesuai Harapan (BSH) dan Berkembang Sangat Baik (BSB). Berdasarkan perolehan nilai anak, dapat dinyatakan bahwa program kegiatan dalam meningkatkan kemampuan membaca permulaan anak melalui media kartu huruf pada Kelompok B TK Kartika XX-46 Kendari secara klasikal pada siklus I mencapai tingkat keberhasilan sebesar 65\% dengan 13 anak, dimana 6 anak memperoleh nilai bintang $(* * * *)$ atau Berkembang Sangat Baik dengan persentase 30 dan 7 anak memperoleh nilai bintang (***) dengan persentase $35 \%$.

Berdasarkan hasil evaluasi tersebut, belum mencapai indikator kinerja yaitu $\geq 75 \%$ maka lanjut pada siklus II. Tindakan pada siklus II yang terdiri atas empat kegiatan harian, peneliti melaksanakan pembelajaran sesuai dengan Rencana Kegiatan Harian (RKH) dengan tema alat transportasi, sub tema alat transportasi udara dengan tema spesifik pesawat, helikopter, balon udara, dan pesawat tempur, yang dilaksanakan pada tanggal 14, 15, 16, dan 17 Maret 2016.

Tindakan penelitian ini dilaksanakan di ruang Kelompok B TK Kartika XX-46 Kendari, anak telah siap belajar dengan guru dengan acuan pembelajaran yaitu peningkatan kemampuan membaca permulaan anak melalui media kartu huruf. Adapun indikator yang akan dicapai pada tiap pertemuan yaitu mengenal simbol-simbol huruf, menyebutkan huruf vokal, menyebutkan kata yang dengan huruf awal yang sama dan menyusun huruf. Setelah perencanaan awal, selanjutnya peneliti yang bekerjasama dengan guru Kelompok B untuk melaksanakan tindakan yang sudah direncanakan. Pada pelaksanaan tindakan ini, peniliti melaksanakan skenario pembelajaran sesuai RKH dengan tema alat transportasi, sub tema alat transportasi udara dengan tema spesifik pesawat, helikopter, balon udara, dan pesawat tempur.

Hasil analisis observasi guru sesuai dengan lembar observasi sebanyak 14 aspek yang harus dicapai oleh guru. Pada siklus II persentase aspek yang diamati mencapai $92,9 \%$ dengan rincian dari 14 aspek hanya 13 aspek yang dilaksanakan. Aspek yang diamati diantaranya yaitu: (a) guru menyampaikan tujuan pembelajaran; (b) guru melakukan apersepsi yang berhubungan dengan tema/subtema pembelajaran; (c) guru menyiapkan media pembelajaran (kartu huruf); (d) guru menjelaskan tujuan pembelajaran/kegiatan yang akan dilaksanakan yang berkaitan dengan media kartu huruf; (e) guru menentukan satu kata yang sesuai dengan tema; (f) guru mengenalkan huruf pada kata yang telah ditentukan; (g) guru mempersilahkan anak untuk menyebutkan huruf vokal; (h) guru mempersilahkan anak untuk menyebutkan kata yang memiliki huruf awal yang sama; (i) guru mengacak kartu huruf; (j) guru mempersilahkan anak secara bergantian menyusun huruf sehingg membentuk kata; (k) guru bimbingan anak dalam menggunakan media kartu huruf; (1) guru mengadakan tanya jawab tentang kegiatan yang telah dilakukan; (m) guru memberikan motivasi, penguatan dan penghargaan pada anak; dan (n) memberikan kesimpulan terhadap kegiatan yang dilakukan hari ini. 
Aspek yang tidak tercapai sebanyak 1 aspek dengan persentase $7,1 \%$ yaitu guru memberikan kesimpulan terhadap kegiatan yang dilakukan hari ini. Untuk lebih jelasnya dapat digambarkan melalui histogram berikut ini:

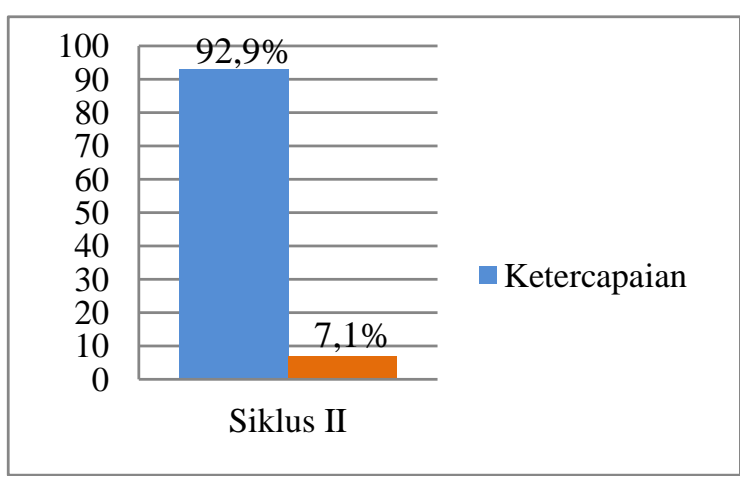

Gambar 4. Histogram Hasil Analisis Aktivitas Mengajar Guru Siklus II

Hasil analisis observasi aktivitas belajar anak sesuai dengan lembar observasi sebanyak 14 aspek yang harus dicapai oleh anak. Pada siklus II persentase aspek yang diamati mencapai $85,7 \%$ dengan rincian dari 14 aspek hanya 12 aspek yang dilaksanakan oleh anak. Aspek yang diamati diantaranya yaitu: (a) mendengarkan guru menyampaikan tujuan pembelajaran; (b) aktif pada kegiatan apersepsi; (c) memperhatikan guru saat memperkenalkan media kartu huruf; (d) mendengarkan penjelasan guru mengenai tujuan pembelajaran/kegiatan yang akan dilaksanakan, berkaitan dengan media kartu huruf; (e) anak antusias bertanya; (f) anak memperhatikan kata; (g) anak menyebutkan huruf pada media kartu huruf; (h) anak menyebutkan huruf vokal pada kata; (i) anak menyebutkan kata yang memiliki huruf awal yang sama; (j) anak berdiri berbaris di ruang kelas; (k) anak menyusun huruf pada kartu huruf menjadi sebuah kata; (l) anak mendapatkan bimbingan dari guru dalam menggunakan media kartu huruf; (m) anak melakukan tanya jawab dengan guru tentang kegiatan yang dilakukan hari ini; (n) anak mendengarkan nasehat-nasehat dan kesimpulan terhadap kegiatan yang dilakukan hari ini.

Aspek yang tidak tercapai sebanyak 2 aspek dengan persentase $14,3 \%$. Untuk lebih jelasnya dapat digambarkan dengan histogram berikut:

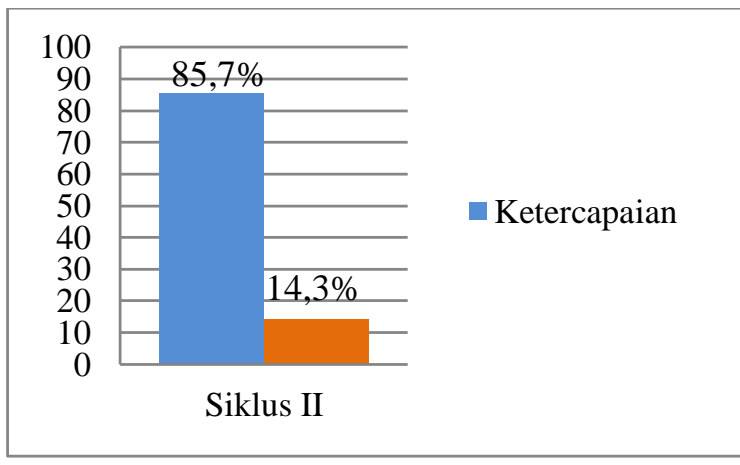

Gambar 5. Histogram Hasil Analisis Aktivitas Belajar Anak Siklus II

Analisis keberhasilan secara klasikal dan diperoleh dari data hasil nilai individual seperti tampak pada tabel 3. berikut ini.

Tabel 3. Perhitungan Nilai Klasikal pada Tindakan Siklus II

\begin{tabular}{ccc}
\hline Kategori & $\begin{array}{c}\text { Jumlah } \\
\text { Anak }\end{array}$ & $\begin{array}{c}\text { Persentase } \\
(\mathbf{\%})\end{array}$ \\
\hline $\begin{array}{c}\text { Berkembang } \\
\text { Sangat Baik (BSB) }\end{array}$ & 12 & 60 \\
\hline $\begin{array}{c}\text { Berkembang Sesuai } \\
\text { Harapan (BSH) }\end{array}$ & 5 & 25 \\
\hline $\begin{array}{c}\text { Mulai Berkembang } \\
\text { (MB) }\end{array}$ & 3 & 15 \\
\hline $\begin{array}{c}\text { Belum Berkembang } \\
\text { (BB) }\end{array}$ & 0 & 0 \\
\hline Jumlah & 20 & 100 \\
\hline Berdasarkan data yang & diperoleh
\end{tabular}
menunjukkan bahwa rata-rata perolehan nilai anak berada pada taraf bintang (****) atau Berkembang Sangat Baik (BSB). Berdasarkan data hasil yang diperoleh pada tabel tersebut terlihat bahwa secara klasikal kegiatan meningkatkan kemampuan membaca permulaan anak melalui media kartu huruf di Kelompok B TK Kartika XX-46 Kendari pada tahap evaluasi siklus II mengalami peningkatan, karena tingkat keberhasilan anak yaitu sebesar $85 \%$. Berdasarkan data tersebut dapat terlihat bahwa anak memperoleh nilai bintang (****) atau Berkembang Sangat (BSB) dengan persentase $60 \%$ yaitu 12 orang anak, 5 orang anak dengan nilai bintang $(* * * *)$ atau Berkembang Sangat Baik (BSB) dengan persentase $25 \%$, dan 3 orang anak memperoleh nilai bintang $(* *)$ atau Mulai Berkembang (MB) dengan persentase $15 \%$.

\section{KESIMPULAN DAN SARAN}

\section{Kesimpulan}


Berdasarkan hasil penelitian yang dilakukan di TK Kartika XX-46 Kendari pada Kelompok B selama dua siklus, maka dapat disimpulkan bahwa kemampuan membaca permulaan dapat ditingkatkan dengan menggunakan media kartu huruf. Hal ini dapat terlihat oleh kemampuan membaca permulaan anak pada saat hasil observasi awal sebelum tindakan sebesar $40 \%$, pada siklus I meningkat menjadi $65 \%$ dan pada siklus II lebih meningkat lagi menjadi $85 \%$, serta berdasarkan hasil observasi guru pada pelaksanaan siklus I, memperoleh persentase sebesar 78,6\% dan pada siklus II meningkat menjadi 92,9\%. Sedangkan hasil observasi aktivitas belajar anak pada pelaksanaan siklus I, memperoleh persentase sebesar $64,3 \%$ dan pada siklus II meningkat menjadi $85,7 \%$.

\section{Saran}

Peneliti menyarankan hal-hal diantaranya: 1.) Bagi guru, sebaiknya guru menggunakan media kartu huruf dalam kegiatan pembelajaran kemampuan membaca permulaan, dengan kartu huruf anak dapat menyusun huruf menjadi sebuah kata. Kegiatan menyusun huruf ini merupakan sarana bermain sambil belajar bagi anak usia dini, serta menarik bagi anak karena terdapat gambar pada kartu huruf. 2.) Bagi sekolah, perlunya menambah kegiatan yang menarik untuk anak dan menyediakan fasilitas yang dibutuhkan yang mendukung kegiatan pembelajaran untuk meningkatkan kemampuan membaca anak.

\section{DAFTAR PUSTAKA}

Arikunto, Suharsimi. 2010. Prosedur Penelitian Suatu Pendekatan Praktek. Jakarta: Rineka Cipta

Arsyad, Azhar. 2011. Media Pembelajaran. Jakarta: Raja Grafindo Persada.

Depdiknas, 2003. Undang-undang Nomor 20 Tahun 2003 Tentang Sistem Pendidikan Nasional Pasal 1 ayat 14 tentang Sistem Pendidikan Nasional. Jakarta: Depdiknas.

Depdiknas. 2004. Pedoman Penilaian di Taman Kanak-Kanak. Jakarta: Depdiknas.

Dewi, Ratna Arini. 2012. Peningkatan Kemampuan Membaca Permulaan melalui Media Kartu Kata Bergambar pada Anak Kelompok $B$ di TK Masyithoh Kedungsari Kulon Progo, [Online].Tersedia:http://eprints.uny.ac.i d/9801/. [28 April 2016].

Dhieni, Nurbiana, dkk. 2006. Metode Pengembangan bahasa. Jakarta: Universitas Terbuka.

Ningsih, Herlina. 2014. Meningkatkan Kemampuan Membaca Awal Anak Melalui Bermain Kartu Huruf Pada Anak Kelompok B PAUD Aulia Kecamatan Tebat Karai Kabupaten Kepahiang, [Online]. Tersedia: http://simki.unpkediri.ac.id/mahasiswa/f ile_artkel/2014/11.1.01.11.0011.pdf. [30 Oktober 2015].

Susanto, Ahmad. 2014. Perkembangan Anak Usia Dini. Jakarta: Kencana Prenada Media Group.

Trisniwati. 2014. Peningkatan Kemampuan Mengenal Huruf Melalui Metode Permainan Kartu Huruf Pada Kelompok B1 TK Aba Ketanggungan Wirobrajan Yogyakarta, [Online]. Tersedia:http://eprints.uny.ac.id/13605/1 /Skripsi\%20Trisniwati\%201011124700 5.pdf [16 Januari 2016].

Waraningsih, Tri Lestari. 2014. Upaya Meningkatkan Kemampuan Mengenal Huruf Menggunakan Media Kartu Kata di TK Sulthoni Ngaglik Sleman, [Online].Tersedia:http://eprints.uny.ac.i d/13530/1/SKRIPSI\%20Tri\%20Lestari \%20Waraningsih\%2010111247002.pdf [16 Januari 2016] 